\title{
Serbian Large Agribusiness Corporations Knocking at the Door of E-Agribusiness Revolution
}

\author{
B. Ž. Ljutić ${ }^{1}$, D. Đurđević ${ }^{2}$, Z. Đorđević ${ }^{3}$, A. Damnjanovićc ${ }^{4}$ \\ ${ }^{1}$ University Business Academia, Faculty of Economics and Engineering Management, Novi Sad, Republic \\ of Serbia. \\ ${ }^{2}$ Academy of National Security, Belgrade, Republic of Serbia. \\ ${ }^{3}$ Ministry of Defence of Serbia, Belgrade, Republic of Serbia. \\ ${ }^{4}$ Faculty of Economics \& Management Dositej, Belgrade, Republic of Serbia
}

\begin{abstract}
Transformation of large agribusiness corporations in Serbia is at its beginning. Institutional investors are taking control of these firms through foreign direct investments. Corporate reorganization of agribusinesses starts up by introducing efficient management, information technology, Net and e-commerce. IT environment generates a new business model, which creates connections in Serbia between the large agribusinesses, business processes and IT. The market of agricultural production in Serbia is rapidly changing and adapting itself to the global trends, mainly to the Internet economy. The speed of transactions and volume of information is increasing dramatically. It is important to explain the basic economic principles at macro and micro levels. Such revolutionary changes affect the operations and management of agribusiness on the Internet and outside of it. The purpose of this work is to stimulate further research in these processes, and to use the acquired knowledge as a tool for efficient corporate agribusiness management.
\end{abstract}

\section{Keywords}

Serbia, e-agribusiness, information technology.

Ljutić, B. Ž., Đurđević, D., Đorđević, Z. and Damnjanović, A. (2016) "Serbian Large Agribusiness Corporations Knocking at the Door of E-Agribusiness Revolution", AGRIS on-line Papers in Economics and Informatics, Vol. 8, No. 2, pp. 57-65. ISSN 1804-1930. DOI: 10.7160/aol.2016.080205.

\section{Introduction}

The main reason for realization of the research is the emergence of the e-commerce in Serbian large agribusiness corporation. The use and perceptions of the development of the Internet and e-commerce in Serbian agribusiness corporations is evident in the media, it has not been tackled as an important scientific research area. We have conducted a questionnaire survey by contacting few large agribusiness corporations, survey of the available data at websites at the public domain. Basic aim of ours research was to start-up research in this area, and to stimulate other researchers, also to review the pertinent literature dominantly from the most developed agribusiness systems and markets, since this area is not covered in the published papers in Serbia not only in the agribusiness but also in the others sectors of the national economy.

Ownership transformation and introduction of new management methods within the big industrial farms, that later became the largest leading agribusiness corporations was a slow process. Socialist farms, cooperatives and agribusiness combined farms were important, while small private farms were dominant, but at the same time not so efficient model of food production in the late 1980s in Yugoslavia, and later on in Serbia. First discussions and paper publications were influenced by the foundation monograph in financial planning in agribusiness, as the key to better and more efficient money management (Schneeberger and Osburn, 1977), as well as by recent analysis of bank finances for agribusiness in open market economy (Joshi and Prasad, 2012). The capital requirements of farms, ranches, small and medium agribusiness required specially prepared management, later on established as farm agribusiness management. More elaborate and comprehensive systems approach to modern agricultural management was the reflection of structured and well balanced 
approach to a trend of larger commercial farms in the USA. This dramatic shift has introduced a requirement for capable, educated operators and farm managers, decision-making skills, based on the corporate financial management principles and doctrine. Initial surveys of e-commerce practices, done by large number of researches, at the beginning were narrowly focused on the industrial and commercial businesses, in order to determine the level of participation in e-commerce and benefits of those activities. One of the pioneering studies on the role of Internet and e-commerce early adoption by agricultural input firms showed that agribusiness companies in the USA were using e-commerce more with their suppliers than with their customers, envisaging that the e-commerce capabilities in agribusiness industry will remain highly diverse in future, as this really happened at the end of the first decade of the $21^{\text {st }}$ century (Henderson, Dooley and Akridge, 2004).

New agribusiness management tools and principles were established to solve complex large-farm operational and strategic development goals and problems (Schneeberger and Osburn, 1983), as a foundation for strategic agribusiness management planning for food chains, centred around gigantic agribusiness corporations (Fava Neves, 2007). Efficient methodological approach to the creation and publication of so called "integrated or unified" reports which include the aspects of environmental, social responsibility, as well as corporate governance reporting of the large agribusiness corporations, adequate to the circumstances in Serbia, as a specific road map, are set as an acceptable proposal. Logical and consequential progress to foundation of the basic principles of agribusiness management was created a few years later as the definition of the agribusiness system at the national level in the USA, as well as of the role of agribusiness manager and corporate planning function, while the focus on applied food economics, at the beginning of the $21^{\text {st }}$ century, intertwined with the agribusiness management and agricultural economics (Beirleing, Schneeberger and Osburn, 1983, 2013), with significant advances in the field of organizational economics in agribusiness (Cook and Barry, 2004). This methodological approach, based on the establishment of the new research and professional field in agro economics we may call "Bible", since it is more than the globally spread standard in high quality textbooks and leading research articles in the USA and all around the world. Colleges, universities, faculties, associations offarmproducersandranchersareusing thisapproach more than any other, according to the number of the footnotes quoted. Bierlein, Schneeberger and Osburn embedded the development of marketing plan and consumer demand within the corporate planning function, forecasting the role of budgeting function. Within the organization they stressed importance of the organized agribusiness for success, especially cooperative large agribusiness farms, which are similar to modern agribusiness corporations in Serbia. The controlling function stresses the element of organized production, based on the sound economic principles, cost management control, financial statement analysis, accounting information systems, capital budgeting. The e-commerce has the strongest, everlasting and increasing impact on the corporate function of the agro-food marketing, generated almost a decade ago as a marketing tool, with an emphasis on agro and organic food, now adopted by the large corporate leaders (Baourakis, Kourgiantakis and Migdalas 2002). Next and promising step is a very fast development of e-commerce personalization, a process easily available to many online vendors. Large agribusiness corporations could be the leaders of this process (Kaptein and Parvinen, 2015).

The corporate directing function is based on the sound supervision mechanisms, staffing the organization with adequate human resources, while the concluding part of this approach has been narrowly focused on the use of IT for better management, and on evaluation of the operating agribusiness. Profound agricultural price and trade policy reforms in developing countries as a whole, and especially in transition economies like Serbian, require efficient agribusiness corporate sector in Serbia, embodied in large agroindustrial corporations (Anderson, Krueger, Schiff and Valdés, 2009). Contemporary development of information technology and commerce through the Internet has been widespread in the EU, and these trends are also reflected in Serbian agribusiness large corporations, mostly local branches of the EU counterparts (Strzebicki, 2014), since they increasingly use electronic commerce. Only a few domestic market leaders, like MK Komerc and PKB Corporation, use electronic commerce, since they form very significant food supply chains on the Serbian market. At Belgrade Stock Exchange only five companies are listed at the primary market as primary issuers (Ljutic, Jankovic and Vlasic, 2012). Out of these mentioned group only one is in the agribusiness sector, Sojaprotein, Becej, which has been covered in our direct survey, since that data on the e-agribusiness are not publicized 
at the stock market web site (Belgrade Stock Market, 2016).

Agricultural markets in Serbia are under the direct influence of the neighbouring countries, mostly the EU members (e.g. Croatia, Slovenia, Austria, Hungary, Bulgaria, Romania, Greece, etc.) Information technology is playing a crucial, dynamic and strong role in business operations and strategy of agribusiness firms and farms in Serbia, regardless of their size, which proves that firms increasingly use e-commerce online tools and techniques (Manouselis, Konstantas, Palavitsinis, Costupoulou and Sideridis, 2009). Also, the necessity of reengineering and refactoring of business processes should be taken into account, with a clear goal to improve the operational efficiency and effectiveness of the e-commerce applications, taking into account the software life cycle, since the few corporate largest agribusiness leaders in Serbia are really making the first inroad steps into e-commerce, creating software solutions which are not best today, but could be improved in the next few years (Distante, Garrido, CamelierCarvajal, Giandini and Rossi, 2014).

In Serbia this approach was accepted, additionally elaborated and in part adjusted to the local institutions, with a vision to influence reforms and changes in the farming and primary agriculture, taking into account present dilemma on the pace of the reform strategy (Schneeberger, Osborn and Ljutić, 1995). Serbia could learn a lot from the China's gradualist approach to reform strategy, while the speed of transition process in Serbian farming sector was much faster compared to China's, and the state farming sector has been melted down and totally privatized, mostly by the foreign institutional investors and large domestic ones (Benzinger, 1998). New possibilities are opened for the credit capacity of local banks, for the role of specialized financial institutions in agriculture production, model of financial management in corporate agribusiness, for definition of managerial goals, short term bank loans, working capital management and working capital loans in agriculture. This approach has established the role of micro finance function at the level of SME, large industrial farms and corporate agribusinesses, mainly in the food processing and marketing. The systems approach to farm production, as well as to SME and large agribusiness established firmly the theoretical approach and practical models of modern agribusiness management in Serbia, based on the pioneering works of Schneeberger and Osburn, from the early 1960s in the USA, just as corporate agribusiness planning as a way of feasibility assessment and project enterprise financing are also based on their works (Ljutić, Schneeberger and Osburn, 2003), (Fante, Giovannucci and Hanway, 2007). The authors have further developed the framework embracing the role of internal and external audit, marginal analysis, costs of farm ownership, of management control problems and early warning diagnostics, while at the same time complex approach to business planning has been covered. The aspects of agribusiness marketing management, investment analysis and decision making process have been also included, but still with a strong focus on microfinance and agricultural banking. The concluding research in these series of monographs has been refocused on the area of agriculture finance, based on the sound micro and macro concepts in finance, with an agricultural policy goal to restructure productive agriculture business performance through the improved financing model (Ljutić, Schneeberger and Osburn, 2006), while re-engineering of agriculture has been an initial step to improve performance of agribusinesses through financing (Mafinisebi, Oguntade, Mafinisebi O., 2010). The authors have defined the position and role of agriculture finance in the institutional environment, comparatively in the USA and Serbia, as well as the significant aspects of the financial stress in agriculture, present even now in 2015/16, almost ten years later, but now as a fully-fledged and deepening financial crisis. The principles of agriculture finance are based on the doctrine of agribusiness management at farms and in corporations, on vital financial management function, business monitoring at the farm level, on the foundation of the contemporary enterprise resource planning (ERP) in agribusiness which incorporates the e-commerce and e-agribusiness as well. Micro financial planning is a base for documented corporate decision making, for improved business organization and resource management, for the use of capital and credit planning. Corporate finance function in the agribusiness firm is stressing the role of external equity, and also the management check-up list for the large agro industrial projects in construction and exploitation. Financial markets, intermediaries and institutions which are serving production agriculture and agribusiness in Serbia even today present a strategic map and creative vision for the much needed reforms and unavoidable necessity to create an adequate infrastructure. As Serbian agriproduct markets are integrating into the EU and global market structures transaction costs do increase, e.g. legal and negotiating costs, which is something that large agribusiness 
corporations must control and manage effectively in order to reduce drastically their total business costs (Fomina and Fomin 2011).

\section{From E-commerce to E-agribusiness}

Electronic commerce (E-commerce, E-business) came like a surfing wave, with the Internet revolution and economy, but after the initial expansion most of the bubble Internet firms disappeared while the E-commerce stayed as the proven approach and concept of electronic applications. Commercial ties between the individual participants and corporate firms are made on the new form of the market, so called "virtual or internet market". E-commerce model should be also based on the business process management in agribusiness, and on the application of the business continuity standards, taking into account the dominant role of the information and computer technology in the corporate performance.

Leading global agribusinesses, even regional and local market leaders are fast adopting innovative internet strategies, causing long-lasting strategic changes in the supply-chain networks, changes that we are not fully aware of at this moment (Henderson, Dooley, Akridge and Carere, 2005). Analysis of introduction and application of the management information system (MIS) or so called "business informatics" in agribusiness enterprises in the Czech Republic revealed the facts that SMEs farm owners dominantly apply information systems technology as a technological approach and solution, using accounting centred information systems, software for primary agriculture and cattle breeding, and the same trend is probably acceptable for the large agribusinesses in Serbia.

The revolutionary breakthrough has many advantages over the classic business market model, like:

- Access to large, and very often to a global market

- Business costs reduction;

- Easy accessibility to all resources and information.

For the large agribusiness corporations in Serbia the physical frontiers, customs and duties, visible and invisible barriers, shall be very soon almost non-existing, since all the hidden monopolies and production control shall be transferred from the state owned enterprises onto private international agribusiness corporations, which naturally and traditionally do not care about the limitations, borders and restrictions. For e-commerce oriented large agribusinesses in Serbia mobile data technologies are "sine qua non", but not on the open base, since the European project called "Farm-Oriented Open Data in Europe" (FOODIE) shall be implemented in the EU in the period 2014-17, addressing the open data security issues, with a goal to improve the efficiency of transportation in primary agriculture, the path Serbia could replicate, based on the EU countries experience and know-how. E-agribusiness does not require employment of additional human resources, and hire of office premises, while operating around the clock. E-agribusiness means the implementation of the E-business concept and it is a model for Agribusiness Corporation functioning, but our personal opinion is that only medium sized agribusiness firms could apply it. Our preliminary research shows that in Serbia there is not any empirical analysis of the success determinants regarding food and agribusiness e-commerce firms, but the model developed by the group of authors (Montealegre, Thompson and Eales, 2007) could be easily and almost without any adaptation applied in Serbia, as the supply chains are not consistently applying the e-commerce approach. For example, the PKB Corporation, from Belgrade, is using that approach to transform important farming and ranching business processes, with the ever increasing application of the Internet technologies and computer networks. PKB Corporation has developed a strong conceptual dynamic model of E-agribusiness based on:

- E-business strategy, as a part of strategic and operational business planning process;

- Operational application of the E-agribusiness in everyday business transactions and decision making process.

PKB Corporation has envisaged the business strategy as well as E-agribusiness, as the processes which join all the business functions and operations, with the ultimate goal to satisfy the clients' needs fully, while achieving the long term strategic goal of the increase of the corporation value. Elements of E-agribusiness strategy include the E-philosophy concept, E-marketing, business strategy and planning, IT and communication infrastructure, while the farm production includes E-farming production, E-technology, E-distribution, E-security (physical and IT infrastructure). While waiting for the new owner the PKB Corporation is considering to introduce business intelligence, customer relationship management (most of the elements are operational nowadays 
but the process is not completed), ERP (significant parts of the ERP systems are implemented, like the accounting, corporate finance, human resources, business information, e-mail and data exchange, etc., but the system needs a full integration and some minor, necessary elements). Great potential is hidden into the open data and open formats, but our latest research is pointing out that further research studies are necessary (Vostrovsky, Tyrychtr and Ulman, 2015).

The intrinsic meaning of the term agribusiness incorporates large-scale corporate farms with industrial background, vertically integrated food production, e.g. corporate farming on a large scale as a contrast to smaller family farms. The core of the agribusiness is integrative in itself (e.g. collective business activities focused on the food production and the final consumption), incorporating the concept of agricultural production and final distribution to consumers. E-commerce is the natural embodiment of this concept and efficient environment for generation of new employment and income.

\section{Materials and methods}

In this research we have applied the standard multi-question, multi-criteria survey, covering ten agribusiness corporations in Serbia, while two of them are the corporate groups based on the Law of Accountancy and Auditing in Serbia and Standard Statistical Classification, EU Stat Standards. These two corporate groups are Victoria Group with ten companies within the Group, and MK Group consisted of seventeen independent companies. The survey covered thirty companies, and some individual companies within the two corporate groups are included separately taking into account the specifics of their operation closely related to agribusiness, the websites for the agribusiness groups, group member companies with dominant agribusiness operations, and other large corporations in the agribusiness sector of Serbia.

\section{Results and discussion}

Our research shows that the studies of managerial structure and E-agribusiness in Serbia do not exist. Large agribusiness firms are not present as publicly traded firms on the A-list of the Belgrade Stock Exchange, so all the privatization from now on shall probably take a form of direct buy-out or acquisitions. Our preliminary study was focused on the two leading corporations, one still state owned, PKB Corporation and the other is MK Group, Novi Sad, Serbia. We have taken into account the impact of the global and the national financial crisis, while aspiring to emphasize the impact of still invisible but strong E-agribusiness phenomena in corporate sector in Serbia.

All the websites as a feature found at the agribusiness company website provide background information about the group and/or company, as well as industrial standard technical information about the products sold. Half of the agribusiness corporations in the sample provide link to other data and information sources at home or abroad. Only $10 \%$ of agribusiness corporations provide a dealer directory with information where the products are sold, and there is a large room for improvement of the web page features in this area. Password protected areas which are only accessible to registered users are utilized by the $40 \%$, and we could expect increase of usage along the parallel development in the whole IT sector of Serbia in using this IT solution. The provision of pricing information at the websites about the products sold is only $30 \%$, that is signalling that the dissemination of price information is still in its starting phase. It is surprising, despite our and the general expectation that the online communities and social networks like chat rooms, bulletin boards, and other forms of online communication are not present at all with $0 \%$ at the sample. The online ordering with the using of traditional means of payment are present at the $30 \%$ of the firms, but the other $30 \%$ of the firms allow online ordering and payment, and two indicators should be observed in parallel, as a sing of significant improvement and the orientation of the large agribusiness in Serbia to make a significant step towards a full transformation to online ordering and payment.

When we are talking about the perceptions of the agribusiness firm managers about the Internet and e-commerce in our survey conducted May $25-30^{\text {th }}, 2016,30 \%$ percent of managers thinks that the e-commerce will fundamentally change the way they do business, which is an indicator that the whole top management structure did not accept the idea and goal at full. Even less they are convinced that the emergence of e-commerce shall greatly reduce the role of local dealers in their industry in the next three years, only $10 \%$ of them, but this low estimate should be considered as a clear warning that the whole process is taking a slow pace. It is evident that only $20 \%$ of managers have perception 


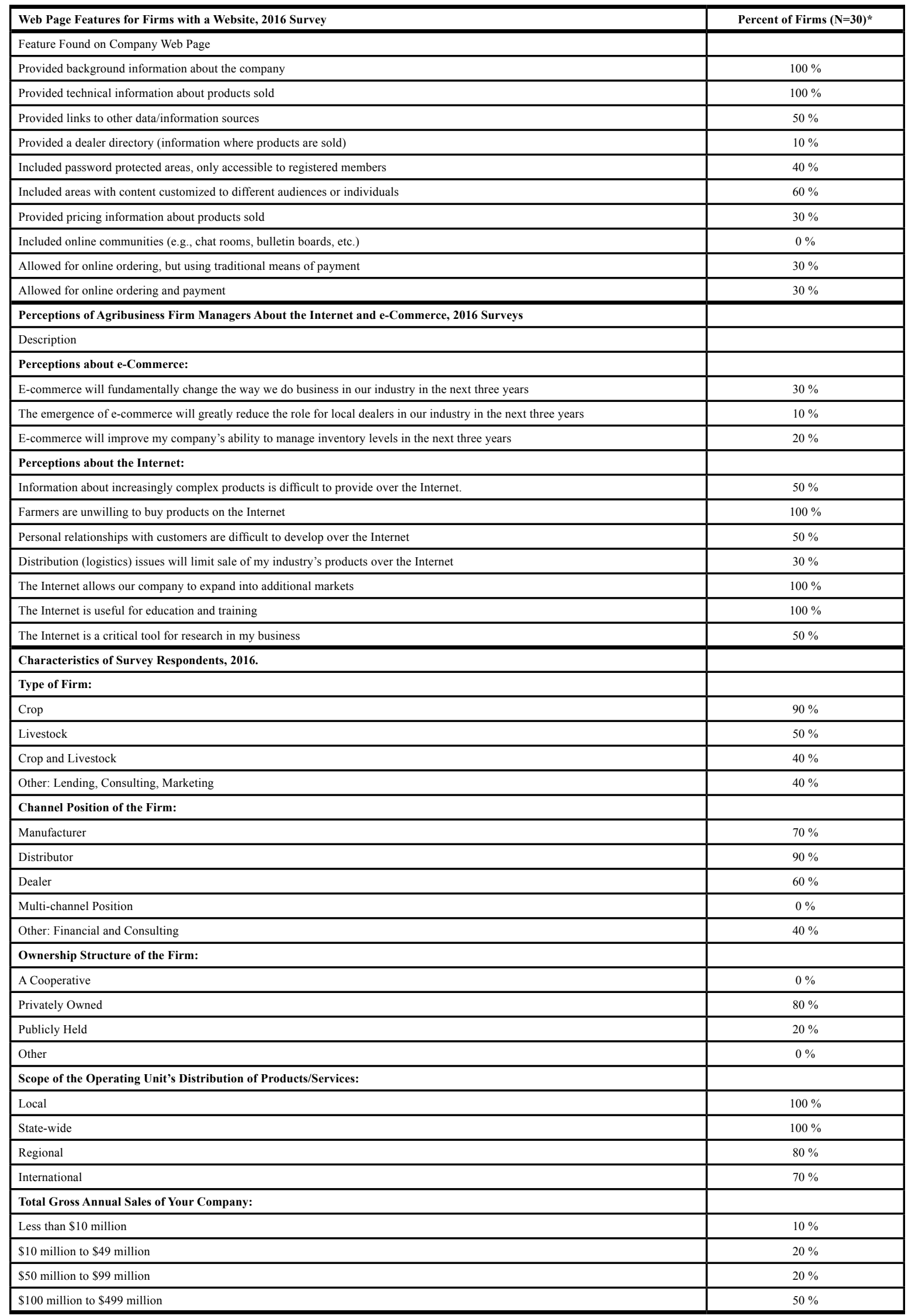

*Notes: Victoria group a.d. - www.victoriagroup.rs, No of members: 10; MK Group, www.mkgroup.rs, No of members: 17; Delhaize Serbia d.o.o. - www.maxi.rs, No of members: 1; $\quad$ Meat Industry Carnex - www.carnex.rs, No of members: 1; Žito-Bačka d.o.o www.zitobacka.com, No of members: 1; Sojaprotein - www.sojaprotein.rs, No of members: 1; IDEA d.d. - www.idea.rs, No of members: 1; Sunoko d.o.o. - www.sunoko.rs, No of members: 1; PTP DIS DOO - www.dis.rs, No of members: 1; Veterinarski zavod Subotica www.vetzavod.com, No of members: 1 .

Source: own processing

Table 1: Features Found on Company Web Page, 2016 Surveys. 
that the e-commerce will improve the corporate capacity to effectively manage inventory levels in the next three years. Perceptions about the Internet use are generally better, with $50 \%$ of respondents considering that the information about increasingly complex products is difficult to provide over the Internet, and rightly that the Serbian farmers are unwilling to buy products on the Internet, something $100 \%$ of the surveyed managers have agreed upon. Half of the managers have a perception that the personal relationship with customers are difficult to develop over the Internet, while even only $30 \%$ are convinced that the distribution and logistics related issues will limit the sale of their products over the Internet. It is very high perception, in both cases with $100 \%$ percent of participants are expecting that the Internet will allow their company to expand to additional markets and at the same time that the Internet is useful for education and training, while only $50 \%$ of managers treat the Internet as a critical tool for research in business.

Firms characteristics of the 2016 sample survey respondents is crop $90 \%$, livestock $50 \%$, crop and livestock $40 \%$ and other (e.g. lending, consulting, marketing) is also $40 \%$. Channel position of the firms is manufacturing $70 \%$, distributor $90 \%$, dealer $60 \%$, multi-channel $0 \%$, and other (financial and consulting) $40 \%$. Ownership structure is cooperatives $0 \%$, privately owned companies $80 \%$, publicly held $20 \%$, and other $0 \%$. Scope of operating unit's distribution of products/services is local $100 \%$, state-wide in Serbia $100 \%$, regional $80 \%$ and international $70 \%$. Gross annuals sale of total company sales are less than $\$ 10$ million $10 \%$, from $\$ 10$ to $\$ 49$ million $20 \%$, from $\$ 50$ to $\$ 99$ million $20 \%$, and from $\$ 100$ million to $\$ 499$ million $50 \%$, based on the official date of the Serbian Business Entity Register - Companies, Data Search (SBRA, 2016).

We have compared our study with the results of the e-business in Croatian agribusiness sector (Tomic, Cerjak and Hadelan, 2012). The authors studied representation of the e-business among Croatian agribusiness sector as a whole, not narrowly focusing as our study only on large agribusiness corporations as market leaders and promoters of change and progress. The study sample included 142 business entities, engaged in agricultural, farming and agribusiness activities, dominantly in primary agriculture (110). The majority of the sample had less than 15 employees $(51,4 \%)$, while at the other extreme were 4,2 \% with more than 500 employees. Agribusinesses with Total Gross Annual Sales over 5.000.000 Croatian Kunas (e.g. 700.00 Euros at prevailing exchange rate at the time of survey). General conclusion of this survey that the firms use Internet banking $(85,7 \%)$, to communicate with suppliers and clients $(74,6 \%)$, while $56,5 \%$ are using Internet as a marketing research tool and $48,5 \%$ for the purchase of input materials. The results of this research provide directions for further research of the development of the e-business in large agribusiness corporations in Serbia and impact on the whole agricultural sector.

\section{Conclusion}

The leading agribusiness corporations are consciously (MK Group) or unconsciously (PKB Corporation) applying and introducing the elements of E-agribusiness which, in turn, in the long term, improve the performances of agribusiness firms, based on their business model and forecasting expectations. The top management teams are still not engaged in monitoring the positive and negative effects of the E-commerce development on the business performance. Top management strategies related to the development and expansion of the E-agribusiness for the large corporations (PKB, MK) understand an inevitable step forward towards increased profits. For example, the MK ZAGA is an E-agribusiness model, based on the ERP approach, which enables the farm production to become a profitable, highly organized business, but it is still in its initial developmental phase. Based on the initial feedback information from respondents from agribusiness firms and their top managers we expect that initial results of this research shall steer up further discussion and research in this field.

\section{Corresponding author:}

Branko Ž. Ljutić, PhD, MA, BA, CA, CPA, Tenure university professor of finance and banking

University Business Academia, Faculty of Economics and Engineering Management

Cvećarska 2, 21000 Novi Sad, Republic of Serbia

Phone: +381641242932,E-mail: ljutic.branko@gmail.com 


\section{References}

[1] Baourakis, G., Kourgiantakis, M. and Migdalas, A. (2002) "The Impact of e-Commerce on Agrofood Marketing: The Case of Agricultural Cooperatives, Firms, and Consumers in Crete", British Food Journal, Vol. 104, No.8, pp. 580-590. ISSN 0007-070X. DOI 10.1108/00070700210425976.

[2] Beierlein, J. G., Schneeberger, K. C. and Osburn, D. D. (2013) "Principles of agribusiness management". Waveland Press. ISBN 978-1577665403.

[3] Beirlein, J. G., Schneeberger, K. C. and Osburn, D. D. (1986) "Principles of Agribusiness Management". A Reston Book, Prentice Hall, Englewood Cliffs, New Jersey. ISBN 0-8359-5599-0.

[4] Belgrade Stock Market (2016) [Online] Available: http://www.belex.rs/eng/trzista_i_hartije/trzista/ prime/akcije [Accessed: 5 June 2016].

[5] Benziger, V. (1998) "Can China's Gradualist Reform Strategy be Applied in Eastern Europe?", Journal of Asia Pacific Economy, Vol. 3, No. 1. [Online]. Available: http://ssrn.com/abstract=120008 [Accessed: 15 February 2016]. DOI: 10.2139/ssrn.131464

[6] Cook, M. and Barry, P. (2004) "Organizational economics in the food, agribusiness, and agricultural sectors“, American Journal of Agricultural Economics, Vol. 86, No.3, pp. 740-743. E-ISSN 1467-8276. ISSN 0002-9092. DOI: 10.1111/j.0002-9092.2004.00617.x.

[7] Distante, D., Garrido, A., Camelier-Carvajal, J., Giandini, R. and Rossi, G. (2014) "Business processes refactoring to improve usability in E-commerce applications", Electronic Commerce Research, Vol. 14, No. 4, pp. 497-529. E-ISSN 1572-9362, ISSN 1389-5753.

[8] Fante, N., Giovannucci, D. and Hanway, C. "The Basics of a Business Plan for Development Professionals“. [Online]. Available: http://ssrn.com/abstract=996767 [Accessed: 1 March 2016].

[9] Fava N. and Marcos, A. (2007) "Method for Demand Driven Strategic Planning and Management for Food Chains", The Chainplan Method. [On-line]. Available: http://ssrn.com/abstract=1007491 [Accessed: 20 February 2016]. DOI: 10.2139/ssrn.1007491.

[10] Fomina, J. and Fomin E. (2011) "Electronic Commodity Market System for Food Networks". Proceedings in System Dynamics and Innovation Food Networks, the International Journal of Food System Dynamics. [Online]. Available: http://centmapress.ilb.uni-bonn. de/ojs/index.php/proceedings/article/view Article/ 163 [Accessed: 8 March 2016].

[11] Henderson, J., Dooley, F., Akridge, J. and Carerre, A. (2005) "Adoption of internet strategies by agribusiness firms". International Food and Agribusiness Management Review. [On-line]. Available: https://www.,esearchgate.net/profile/Jay_Akridge/publication/ 23941188_Adoption_of_ Internet_Strategies_by_Agribusiness_Firms/links/02e7e5188 0156bd3ab000000.pdf [Accessed: 8 March 2016].

[12] Henderson, J., Dooley, F. and Akridge, J. (2004): "Internet and E-Commerce Adoption by Agricultural Input Firms", Review of Agricultural Economics, Vol. 26., No. 4, pp. 505-520. E-ISSN: 1467-9353. DOI: $10.1111 / \mathrm{j} .1467-9353.2004 .00196 . x$.

[13] Joshi, G. V. and Prasad, K. (2012) "Bank Finance for Agribusiness in a Dynamic Setting", Nitte Management Review, Vol. 06, Issue 02, pp. 46-52. [On-line]. Available: http://ssrn.com/ abstract $=2260225$ [Accessed: 9 February 2016]. ISSN 2395-1907.

[14] Kaptein, M. and Parvinen, P. (2015) “Advancing E-Commerce Personalization: Process Framework and Case Study", International Journal of Electronic Commerce, Spring 2015, Vol. 19, No. 3, pp. 7-33. ISSN 1086-4415. DOI 10.1080/10864415.2015.1000216.

[15] Kym, A. (2010) "Krueger, Schiff, and Valdes Revisited: Agricultural Price and Trade Policy Reform in Developing Countries since 1960", Applied Economic Perspectives and Policy, Vol. 32, No. 2, pp. 195-231. [On-line]. Available: http://aepp.oxfordjournals.org/content/32/2/195.full [Accessed: 27 April 2016]. DOI: 10.1093/aepp/ppq005. 
[16] Ljutic, B. Z., Jankovic, S. and Vlasic D. (2012) "Impact of Notes to Financial Statements on the Quality of Financial Reporting: Selected Evidence of Issuers at the Primary Stock Makets in Croatia and Serbia“. $9^{\text {th }}$ ICAFT, International Conference on Accounting and Finance, European and World Experience and Public Policy Consideration, $11^{\text {th }}-14^{\text {th }}$ October, 2012, Riga, Latvia

[17] Ljutić, B. Ž., Schneeberger, K. C. and Osburn, D. D., (2003) “Modern Agribusiness Management: A Systems Approach to Farming and Agribusiness", In Serbian language only: Moderni agrobiznis menadžment. Sistemski pristup farmerskoj proizvodnji i agrobiznisima. Magistar biznis administracije - MBA Press Inc., Beograd. ISBN 86-903871-1-0.

[18] Ljutić, B. Ž., Schneeberger, K. C. and Osburn, D. D. (2006) “Agriculture Finance: Micro and Macro Concepts", In Serbian language only: Agrarne finansije: Mikro i makro koncepti. Magistar biznis administracije - MBA Press Inc., Beograd. ISBN 86-903871-4-5 978-86-903871-4-4.0.

[19] Mafimisebi, T. E., Oguntade, A. and Mafimisebi, O. (2010) "Re-Engineering Agriculture for Enhanced Performance Through Financing“, Journal of Economics, Finance \& Administrative Science, Vol. 15, No. 29, pp. 38 - 49. [Online] Available: http://ssrn.com/abstract=1717956 [Accessed: 9 February 2016]

[20] Manouselis, N., Konstantas, A., Palavitsinis, N.;,Costopoulou, C., Sideridis, A. B. (2009) “A Survey of Greek Agricultural E-Markets“, Agricultural Economics Review, Vol. 10, No.1, pp. 97-112. ISSN 1109-2580

[21] Montealegre, F., Thompson, S. and Eales, J. (2004). „An empirical analysis of the determinants of success of food and agribusiness E-Commerc firms", Doctoral dissertation, Department of Agricultural Economics, Purdue University. [Online] Available: https://www.researchgate. net/profile/Sarahelen_Thompson/publication/23941221_An_Empirical_Analysis of_the_Determinants_of_Success_of_Food_and_Agribusiness_E-Commerce_Firms/ links/02e7e533ea85976682000000.pdf [Accessed: 8 March 2016].

[22] Schneeberger, K. C., Osborn, D. D. and Ljutić, B. Ž. (1995) "Financial Planning in Agriculture: With the Element of Agriculture Credit. A Key to Financial Management of Credit and Money", In Serbian language only: Finansijsko planiranje u agrobiznisu: Sa elementima agrarnog kredita - Ključ za finansijski menadžment kreditom i novcem. ISBN 86-7094-001-9.

[23] Schneeberger, K., C., Osburn, D. D. (1983): “Modern Agricultural Management: A Systems Approach to Farming". Reston Publishing Company, Inc. A Prentice Hall Company, Reston, Virginia. ISBN 0-8359-4550-2.

[24] SBRA (2016) Serbian Business Registers Agency, Registers, Companies. [Online] Available: http://www.apr.gov.rs/eng/Registers/Companies/Search.aspx [Accessed: 5 June 2016].

[25] Schneeberger, K., C. and Osburn, D. D. (1977) "Financial Planning in Agriculture: A Key to Credit and Money Management", The Interstate Printers \& Publishers, Danville, Illinois, Library of Congress Catalog Card No. 77-78698.

[26] Strzebicki, D. (2014) "The Development of Electronic Commerce in Agribusiness - The Polish Example", $2^{\text {nd }}$ Global Conference on Business, Economics, Management and Tourism, 30-31 October 2014, Prague Czech Republic, Procedia Economics and Finance, 23 (2015). ISBN 1314-1320.

[27] Tomic, M., Cerjak, M. and Hadelan, L. (2012) "E-business in Croatian agribusiness", 47 Croatian and $7^{\text {th }}$ International Symposium on Agriculture, Opatija, Croatia, 13-17 February 2012, Proceedings 2012, pp. 231-234. ISBN: 978-953-7878-04-7.

[28] Vostrovsky, V., Tyrychtr, J. and Ulman, M. (2015) "Potential of Open Data in the Agricultural eGovernment", Agris on-line Paper in Economics and Informatics, Vol. 7, No. 2, pp. 103-113. ISSN 1804-1930. 